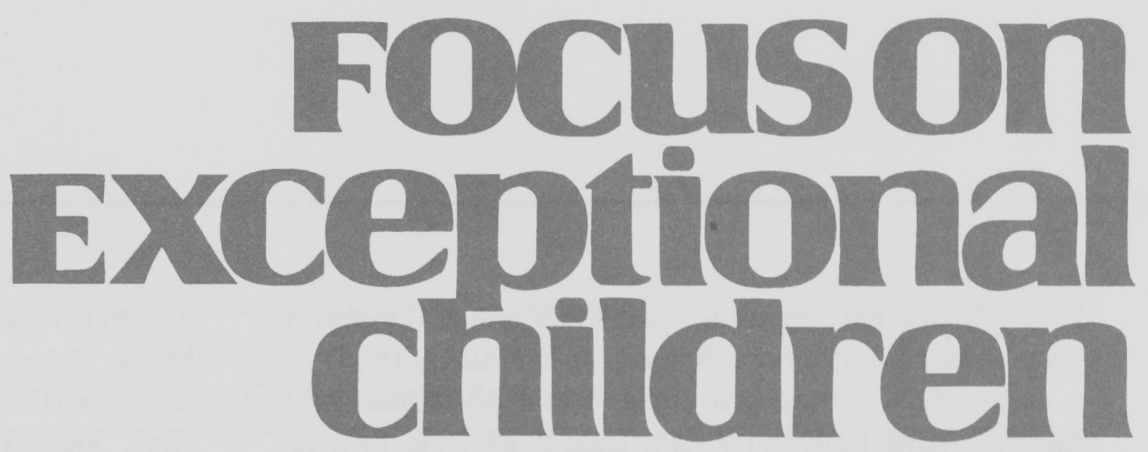

\title{
In Pursuit of Excellence: \\ The Past as Prologue to a Brighter Future for Special Education
}

\author{
Marcia L. Rock, Beth K. Thead, and Robert A. Gable \\ with Michael L. Hardman and Richard Van Acker \\ By failing to prepare, you are preparing to fail." \\ -Benjamin Franklin
}

Any attempt to speculate about the future is likely to be hindered by an imprecise and inadequate understanding of the past, and predicting the future of special education is no exception. Nonetheless, various authors have undertaken that challenge and have done so by examining critically the relatively turbulent, albeit brief history of the field. In most instances they have relied on strategies based on social psychological theory (Bentler \& Speckart, 1981; Speckart \& Bentler, 1982). Though by no means perfect, this approach represents a relatively reliable way to plot a future course of action with regard to both special education policy and practice.

To gain a better understanding of what is entailed in "future scanning," we reviewed the professional literature relating to special education, concentrating on works published between 1994 and 2005. In all, we found 125 articles pertaining to the future of special education (see Table 1). What emerged from that review was a multidimensional perspective on both process (e.g., probability of occurrence, impact) and subject matter (e.g., mainstreaming, inclusion) (Wagschall \& Lucas, 1983). Next, we invited two nationally recognized authorities in the field of the special education to share their thoughts on the future of special education. We hoped to establish a link between the past, present, and the future and, in turn, look for possible ways to influence educational services positively and enhance the life changes of individuals with exceptionalities and their families.

Careful analysis of the work of those who have attempted to predict the future led us to two distinct themes that are apparent and important to consider. One theme involves the early struggles within an emerging field of special education. Preceding passage of Public Law 94-142, special education researchers, practitioners, parents, and advocates had focused primarily on ways to assure students with exceptionalities equal access to public education services (Bryan, 1999). The second theme reflects more recent education reform

\footnotetext{
Marcia Rock and Beth Thead are affiliated with the University of Alabama, and Robert Gable with Old Dominion University. Michael Hardman is with the University of Utah, and Richard Van Acker is with the University of Illinois at Chicago.
} 
efforts. Today, the goal is to establish a quality system of special education (Putnam, Spiegel, \& Bruininks, 1995).

Various factors have converged to impede attainment of that goal-perhaps the most significant of which is the problem-saturated nature of special education. In our review, we found ample evidence of redundancy among past and present issues that prognosticators continue to revisit. We distilled the most common and repetitive issues into the following six themes:

1. Willful ignorance

2. Shots in the dark

3. Broken promises

4. Problematic paradigms

5, Vacuums of popular opinion

6. Detrimental effects

With these themes in mind, what follows are two perspectives on the future of special education.

First, Michael Hardman shares his thoughts about policy as it relates to general and special education. Then Richard

\section{Focuson
Exceptional
children}

ISSN $0015-511 \mathrm{X}$ FOCUS ON EXCEPTIONAL CHILDREN (USPS 203-360) is published monthly except June, July, and August as a service to teachers, special educators, curriculum specialists, administrators, and those concerned with the special education of exceptional children. This publication is annotated and indexed by the ERIC Clearinghouse on Handicapped and Gifted Children for publication in the monthly Current Index to Journals in Education (CIJE) and the quarterly index, Exceptional Children Education Resources (ECER). The full text of Focus on Exceptional Children is also available in the electronic versions of the Education Index. It is also available in microfilm from Xerox University Microfilms, Ann Arbor, MI. Subscription rates: individual, \$36 per year; institutions, \$48 per year. Copyright (C) 2006, Love Publishing Company. All rights reserved. Reproduction in whole or part without written permission is prohibited. Printed in the United States of America. Periodical postage is paid at Denver, Colorado. POSTMASTER: Send address changes to:

Love Publishing Company

Executive and Editorial Office P.O. Box 22353

Denver, Colorado 80222

Telephone (303) 221-7333

\section{EDITORIAL BOARD}

Edwin Ellis

University of Alabama
Tim Lewis

University of Missouri

Chriss Walther-Thomas

University of Kansas

Susan T. Warhover Editor
Stanley F. Love

Publisher
Van Acker discusses past-to-present practices in special education. Interestingly, as you will discover, many of their thoughts mirror past sentiments expressed by experts in the field. Viewed together, they afford us an opportunity to examine carefully the past struggles and, within that context, look to the future of special education.

$$
* * *
$$

\section{Outlook on Special Education Policy Michael L. Hardman}

\section{PAST-TO-PRESENT ACCOMPLISHMENTS IN SPECIAL EDUCATION POLICY}

\section{From Access to Accountability in Federal Special Education Policy}

For three decades the Individuals with Disabilities Education Act (IDEA) has provided access to a free and appropriate public education for millions of students with disabilities. In today's schools, access to education on an equal basis is national policy. For most of the 20th century, however, the availability of public education for children with disabilities was sporadic and selective. Even with the U.S. Supreme Court decision in Brown v. Board of Education (1954) and the passage of the Civil Rights Act in 1964, most states merely allowed for special education; they did not mandate it. Federal policy was silent while many states openly excluded children with disabilities from public schools. For example, North Carolina schools were allowed to define certain children as "uneducable," and schools prosecuted parents as nuisances if they attempted to challenge such a decision (Hardman \& Nagle, 2004).

In the 1960s, President John F. Kennedy called for an expanded federal role in special education policy, providing financial support to the states for the preparation of special education teachers and research on "education of the handicapped." The Bureau of Education for the Handicapped $(\mathrm{BEH})$ in the Office of Education (presently the Office of Special Education and Rehabilitative Services in the U.S. Department of Education) was created as a clearinghouse for information on special education.

The evolution of federal special education policy continued into the 1970s, becoming rooted in the 14th Amendment to the U.S. Constitution through class action lawsuits in Pennsylvania (Pennsylvania Association for Retarded Children v. Commonwealth) and the District of Columbia (Mills v. Board of Education). By the mid-1970s, the right to education had become a major national policy issue. At that time, about one in four students with disabilities were excluded from school and more than half were not receiving an appropriate education (Hardman \& Nagle, 2004). 
TABLE 1

Journals Publishing Forecasting Articles

Journal Year

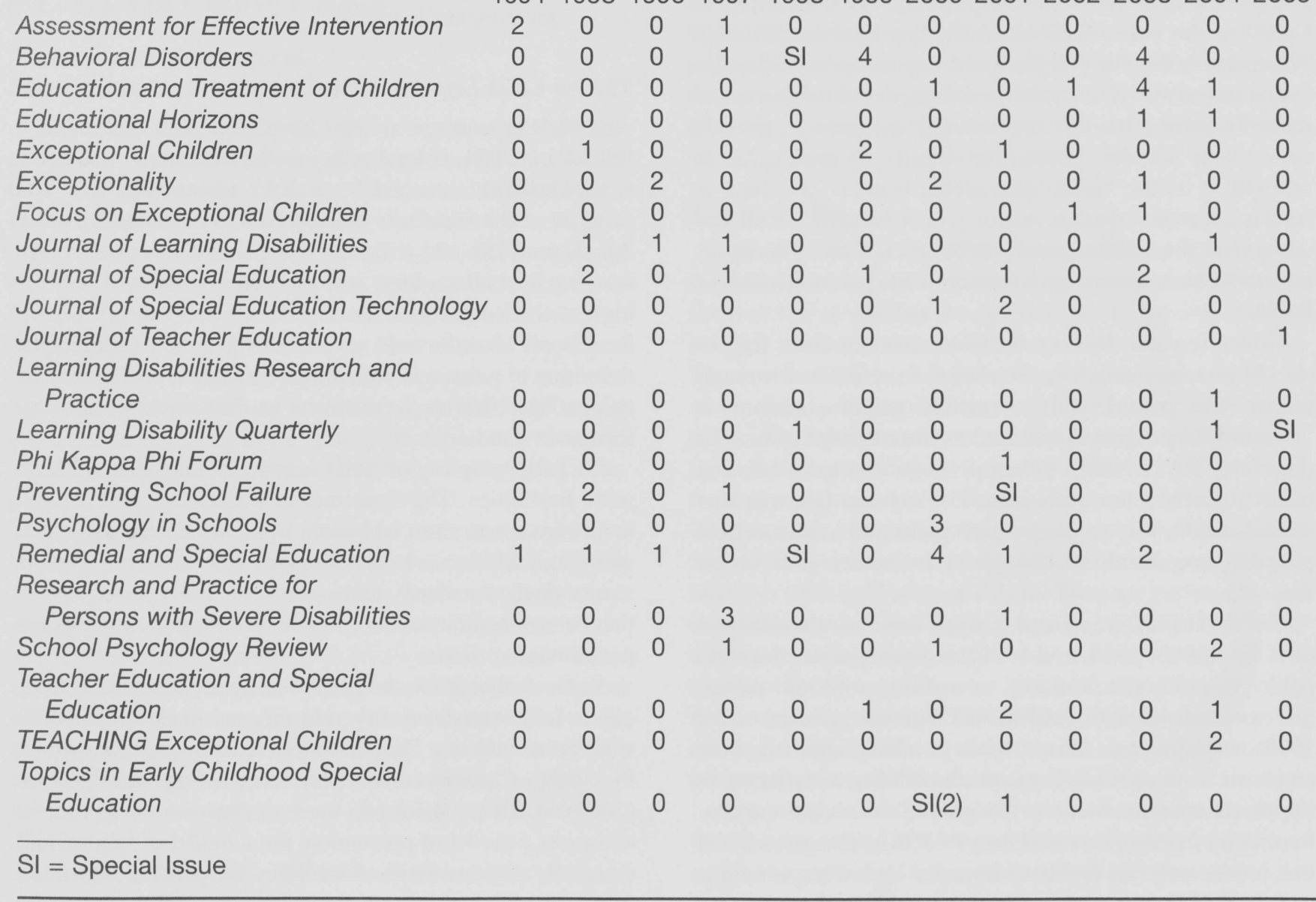

\section{The Education for All}

\section{Handicapped Children Act and IDEA}

As litigation involving the right to education increased in many states, the evolution in federal special education policy reached its pinnacle in 1975 with the passage of the Education for All Handicapped Children Act (Public Law 94142), renamed the Individuals with Disabilities Education Act (IDEA) in 1990. Framed on the principle of zero exclusion, IDEA requires that every eligible student with a disability receive a "free and appropriate public education" (FAPE).

Few would argue that for the past 30 years special education has been driven by the requirements of IDEA. The law mandates-from the state agency to the classroom teacher-a specific process that must be followed to ensure that students with disabilities receive an appropriate educational experience. The basic tenets of IDEA include

- eligibility based on nondiscriminatory and multidisciplinary assessments,

- parent involvement and consent,

- an individualized education program, and

- educational placement in the least restrictive environment.

IDEA's procedural requirements have changed very little in the time it was originally passed. As constructs that define 
special education policy, they are linked inexorably to both research and practice. As public policy, IDEA's basic tenets are relatively secure because of their permanent authorization in federal law (Hardman, McDonnell, \& Welch, 1997).

Although the right to FAPE for every student with a disability is at the heart of federal policy, the courts have had to interpret Congressional intent repeatedly. The U.S. Supreme Court, in the case of Hendrick Hudson District Board of Education v. Rowley (1982), stated that an appropriate education consists of "specially designed instruction" and related services that are "individually designed to provide educational benefit" (201). The Court's interpretation is referred to as the "some educational benefit" standard. A state is not required to provide an ideal education for all students with disabilities, merely a beneficial one. The Court concluded that "meaningful access" is the primary intent of IDEA.

Following the Rowley decision, lower courts had to decide just how much "educational benefit" was enough to provide "meaningful" access. Most have adopted a "meaningful progress" standard as the measure of benefit (Huefner, 1991, 2000). Token progress toward achieving these goals was not sufficient. The expectation was that schools find a way to measure progress and to ensure that progress is substantial enough to be meaningful to the student.

For the first 22 years and through three reauthorizations of IDEA (1983, 1986, and 1990), federal special education policy was directed primarily to ensuring access to education for students with disabilities. With the passage of the 1997 amendments, federal policy makers shifted their emphasis from accessibility to accountability, as reflected in improved outcomes within the general education curriculum. In its findings on the history of IDEA, Congress noted that implementation had been impeded by low expectations and an insufficient concentration on applying research on proven methods of teaching and learning for children with disabilities.

\begin{abstract}
Over 20 years of research and experience has demonstrated that the education of children with disabilities can be made more effective by having high expectations for such children and ensuring their access in the general curriculum to the maximum extent possible. (IDEA 1997, Part A, Section $601[c])$
\end{abstract}

The congressional view was corroborated by research in the 1990s strongly suggesting that schools had lower expectations for students with disabilities in comparison to their nondisabled peers, as evidenced by the exclusion of students with disabilities from state and local tests (Ingels, 1996; McGrew, Vanderwood, Thurlow, \& Ysseldyke, 1995). To deal with this concern, IDEA 97 linked the concepts of educational benefit and meaningful progress to accessing the general curriculum and participation in the same assessments as peers without disabilities. Two new tenets were embedded in the law:

1. Access, involvement, and progress in a challenging general education curriculum

2. The need to make education agencies accountable for students' learning

\section{The No Child Left Behind Act}

With the passage of the No Child Left Behind Act (NCLB) in 2001, federal policy in the education of students with disabilities reached beyond the tenets of IDEA. The promise of the standards era and NCLB is straightforward: All students can and will learn more than they currently are learning, and all students will succeed if schools expect the highest academic standards. If students don't succeed, public schools must be held accountable for their failure. The definition of success is determined by student proficiency on content specified by the state and as measured by state performance standards.

NCLB's promise of "all means all" includes students with disabilities. The fundamental purpose of NCLB is to assure access to the curriculum upon which the standards were based, access to assessments that measure performance on the standards, and inclusion in the reported results that determine how well a school is meeting the established performance criteria.

In December 2004, the Individuals with Disabilities Education Improvement Act (herein referred to as IDEA 2004) was signed into law. Responding to recommendations of the President's Commission on Excellence in Special Education (2002), IDEA 2004 focuses more on "results-not process; embraces a model of prevention, not a model of failure; and considers children with disabilities as general education first" (p. 12-13). Many provisions in IDEA 2004 are directly aligned with the accountability and "highly qualified teacher" requirements in NCLB. Performance goals on each student's individualized education plan (IEP) must conform to a state's definition of "annual yearly progress (AYP)" as required in NCLB. Students with disabilities are an identifiable subgroup under NCLB, and their progress as measured by AYP must be disaggregated and reported publicly (Mandlawitz, 2006).

In addition, every special education teacher who provides primary instruction in core academic subjects (such as reading, math, science, English, history, biology) must meet the "highly qualified teacher" standard as mandated in NCLB. Other new initiatives are directed to reducing excessive paperwork associated with the IEP; reducing litigation between parents and schools; reducing the disproportionate representation of racial and ethnic groups in 
special education; and clarifying discipline procedures for students with disabilities who violate a school's code of conduct.

\section{PERSISTENT AND UNRESOLVED CHALLENGES: SPECIAL EDUCATION POLICY}

\section{Symbolism or Substance in Federal Special Education Policy?}

One might argue that federal policy has brought about the realization of an extremely important goal-ensuring access to a free public education for students with disabilities. Indeed, the number of students with disabilities in America's schools has more than doubled since P.L. 94-142 was passed in 1975. But these numbers reveal only one side of what is involved in FAPE. The definition of what constitutes an "appropriate education" remains at issue. Should "appropriate" be defined and measured by the acquisition of core academic content as defined in NCLB and IDEA 2004? Or should it be linked to learning skills that promote access to valued post-school outcomes, including employment, independent living, or further education.

One view is that schools should be more accountable for whether students with disabilities achieve skills leading to valued post-school outcomes rather than exclusively measuring proficiency in academic content (Hardman et al., 1997; McDonnell, Hardman, \& McGuire, in press). Some assert no evidence suggests that access to academic content will actually lead to sustained higher levels of achievement among students with disabilities or whether the skills acquired through this curriculum are essential to the successful transition from school (McLaughlin \& Tilstone, 2000)

Laski (1997) has offered a different view, one in which an appropriate education is defined by progress in academic content. He suggests that a student with a disability is entitled to an education that produces substantive benefits. Although the courts have yet to establish a single standard for all students with disabilities, the standards do require a measure of "academic progress." Florien and Pullin (2000) indicate, however, that academic progress alone does not signify the provision of FAPE. Based on court decisions and federal regulations following the Rowley case, those authors suggest that the definition of appropriate education under IDEA has broad meaning and that it includes the services necessary for a student to attain desired outcomes, in addition to any programming needed to address their supplemental individualized needs.

Regardless of the differing professional viewpoints on what constitutes FAPE, current federal policy is grounded in how students perform in core academic subjects (e.g., IEP performance now must conform to a state's definition of AYP). The fundamental promise of federal policy - as manifested in both NCLB and in IDEA 2004-is that all students with a disability can and will learn more than they are currently learning in core academic subject areas. The goal is for every student, including those with disabilities, to be on grade level in reading, math, and science by the year 2014. The underlying premise of NCLB is that this will happen only if schools expect the highest academic standards. If students fail to meet proficiency standards on content specified by the state, and as measured by state performance standards, schools must be held accountable.

\section{Accountability}

Although NCLB and IDEA 2004 provide strong impetus for schools to improve results for students with disabilities, the true test is whether the symbolism of "leaving no child behind" will translate into substantive student learning. Those who believe that federal policy will meet this test assert that including students with disabilities in the state accountability system forces schools to be serious about their learning (National Research Council, 1997). Thus, from a moral standpoint, supporters see NCLB and IDEA 2004 as a direct negation of prior public policy that excluded and devalued students with disabilities. In the past, schools have not been held accountable for the poor performance of their students and have largely regarded the IEP as perfunctory paper compliance rather than an accountability tool (Sebba, Thurlow, \& Goertz, 2000). Today, federal policy forces schools to use the IEP as an accountability blueprint, altering annual goals as necessary to ensure that students progress in the general education curriculum.

In contrast to this positivistic view, others seriously doubt that current policy actually will move from symbolism to substance. Although major professional and parent associations (e.g., the National Education Association [NEA] and the National Parent Teacher Association [PTA]), support the intent of NCLB as it relates to better results for every child, they express concern that federal policy has moved away from assisting states in improving educational programs to mandating compliance. Those who espouse this more negative view argue that the federal government no longer is working with states to provide guidance for improvement but, instead, is imposing stringent requirements and administering severe punishment without providing needed fiscal resources. NEA also is concerned that the law is focused on privatization, an open-market educational system, rather than teacher-led, family-oriented solutions to improving student performance.

The National PTA (2005) suggests that NCLB relies too heavily on testing as the primary measure of systemic accountability, at the expense of other important indicators, 
such as equity of resources, class size, instructional methodology, and more parent involvement. The PTA's concern is reinforced by McNeil (2003), who believes that the accountability movement, as advocated through NCLB, places too much emphasis on problems with teachers-the professionals with the least amount of authority and the most responsibility within schools. The law "diverts attention from the historical inequities in funding, staff allocation, investment in materials, and social support from the broader community" (p. 733).

Yet another view is that NCLB and IDEA 2004 will not succeed because of insufficient instructional time and resources to meet the needs of students with disabilities. In addition, from this perspective, establishing content standards for students with disabilities at the state level is inconsistent with the concept of individualization. If all students are expected to reach the same standard, the bar will have to be lowered to accommodate students with lesser ability. If the bar isn't lowered, students with disabilities will routinely fail to meet the standard.

As others before her, McLaughlin (1998) found that some teachers feel powerless because they believe that all students cannot reach the required standard. These teachers suggest that the aim of including all students in system assessments should be on demonstrating progress (growth) rather than on absolute criteria. Kauffman (1999a) argues that expecting all students to cope with a common standard is unrealistic and potentially damaging. Although improved results in both general and special education clearly are needed, students with disabilities are unlikely to "catch up" to their peers who are not disabled. Actually, accumulated evidence suggests that students may fall even farther behind.

Finally, if current federal policy is to be successful, NCLB's emphasis on standardized assessments must be aligned with IDEA's provisions for special modifications and accommodations deemed appropriate for the student to access the general education curriculum. As Thurlow (2000) posited, participation of students with disabilities in statewide and district-level assessments is linked intimately to the availability of accommodations. Despite the requirement that all students with disabilities must participate in state and district assessments, including reading, math, and science, many of the accommodations and modifications that the IEP team deems appropriate actually may invalidate students' scores. In addition, multiple-choice questions do not necessarily allow students to demonstrate the full depth of their knowledge (Rouse, Shriner, \& Danielson, 2000). As such, students with disabilities may meet AYP goals but be unable to demonstrate their knowledge on the assessments given under standardized conditions (Albrecht \& Joles, 2003).

\section{Authentic Assessments}

Notwithstanding several decades of criticism, the standardized achievement test is still the most common method of measuring performance. Recently, some states and districts have developed more authentic methods of assessing students' academic performance. Authentic assessments of students' learning include individual or group performance of specific skills, portfolio presentations and projects, exhibitions, or demonstrations. Although authentic testing may be intuitively appealing on an emotional level, at a more practical level myriad issues remain to be resolved. Foremost among these is the reality that authentic assessments are time-consuming to create and monitor. From a technical perspective, researchers have voiced concern regarding the technical adequacy of comparing performance-based assessments over many students (Rouse et al., 2000).

\section{BACK TO THE FUTURE WITH FOCUSED EXCELLENCE: CHARTING A COURSE OF THOUGHTFUL ACTION}

\section{Enhancing Future Special Education Policy}

As we chart a course for the future of special education policy, a fundamental question arises: Will the participation of students with disabilities in a standards-based curriculum actually result in higher academic achievement, or is failure an inevitable outcome? Although there is considerable agreement with the intent of NCLB and IDEA 2004 to improve student learning, views differ widely as to whether this realistically can be accomplished in the context of current policy. Previous legislation was criticized similarly. In addressing this issue, policy makers must fund the critical research that eventually will support (or refute) the assumption that a standards-based education system will improve results for all students, including those with disabilities. Without such empirical evidence, public policy will continue to be punctuated by a diversity of opinion regarding what constitutes sound administrative and organizational policy.

A second issue that relates to the question of success or failure is the promise implicit within federal policy that every student will have an opportunity to learn. Despite the impressive body of research that has accumulated to show that opportunity to learn is integral to successful student performance, states have not embraced opportunity-to-learn (OTL) standards as originally conceptualized under the Goals 2000: Educate America Act. As defined in this federal law, OTL standards include "sufficiency or quality of the resources, practices, and conditions necessary at each level 
of the education system." Moving from policy to practice, this translates into

1. assessments and curricular materials that are accessible to every student,

2. the use of evidence-based instruction consistent with individual need and ability, and

3. sufficient material and human resources to deliver the instruction and assess student learning.

Not unlike past critics, Thurlow (2000) suggested that federal policy clearly has outpaced "the technology of standards-based education and assessment" (p. 12), forcing the system to try to catch up. For example, the testing and curriculum development industry has yet to successfully develop or revise assessment instruments or instructional materials that are accessible to every student or can accommodate their individual needs. For students with disabilities, the concept of "catching up" means that schools must promote and use instructional practices that have proven to be highly effective in meeting their increasingly more diverse needs. As such, the question could be: Can a system based on common standards that must be learned within a specified timeframe be compatible with what we know about the characteristics of effective special education practice?

The characteristics of effective special education practice include an individualized approach to learning, intensive instruction, and the explicit teaching of discrete skills (National Research Council, 1997). The longstanding hallmark of special education is individualization. While, historically, general education has been guided by a utilitarian approach (the greatest good for the greatest number), special education practice has been driven by individually referenced decision making. The special education teacher must plan and adjust curriculum and instruction continually in response to the student. Given the differing paradigms in general and special education, the question arises as to the willingness and capacity of schools to recognize and accommodate the growing heterogeneity of variables within schools. The future challenges for state policy makers are many (McLaughlin, 1998; Thurlow, 2000):

- Ensure that content and performance standards are broad enough to meet the individual and diverse needs of students with disabilities.

- Extend the assessment system to include students with disabilities who require accommodations to demonstrate the mastery of knowledge and skills.

- Use assessment results to improve students' learning by changing instructional practice.

Intensive instruction involves the following (McLaughlin, Fuchs, \& Hardman, 1999):
1. Actively engaging students in their learning by requiring high rates of appropriate responses to the material presented

2. Carefully matching instruction to the student's ability and skill level

3. Providing instructional cues and prompts to support learning and then fading them-when appropriate

4. Providing detailed feedback that is directed explicitly to the task the student is expected to complete

Intensive instruction can significantly improve academic achievement and the learning of functional/life skills for students with disabilities across ability levels (Billingsley, Liberty, \& White, 1994; Elbaum, Vaughn, Hughes, \& Moody, 2000; O'Connor, 2000; Torgesen, 1996). For intensive instruction to be effective, however, students will need additional time and resources, as well as access to teachers who effectively use evidence-based practices consistent with individual need and ability. Unfortunately, providing students more time and resources may be incompatible with the standards-based approach in many schools. Students not only must learn specified content but also must do so within a limited timeframe. Students must make AYP at a rate and proficiency level consistent (on-level learning) with sameage peers without disabilities. In the end, policy makers must be willing to ensure that students with disabilities have both sufficient time and resources to be successful in a standards-driven system.

In addition to needing individualized and intensive instruction, students with disabilities often require more structured and teacher-directed approaches to learning than their classmates without disabilities (Carnine, 2000; Peterson \& Hittie, 2003; Stein, Carnine, \& Dixon, 1998; Tarver, 1996). Schools must ensure that these students have the opportunity to learn skills that are outside of the specified academic content designated in state standards (e.g., learning strategies, functional or independent living, and social skills).

According to the National Research Council (2001), students with disabilities require highly structured and explicit instruction to develop the process and understanding that most other children learn more readily and naturally. It follows that if every student is going to perform successfully in a standards-driven environment, policy makers and school officials must support multiple approaches to instruction that take into account the needs of everyone, including those with disabilities. That can be accomplished in various ways, including multilevel instruction, universal design, and assistive technology.

Multilevel instruction requires that teachers accept individual goals within the curriculum and allow students to demonstrate progress in various ways. Universal design for 
learning (UDL) goes beyond multilevel instruction, creating instructional programs and environments that work for all students, to the greatest extent possible, without the need for adaptation or specialized design. Within UDL, a range of options is available to each student that supports access to, and engagement with, the learning materials (Rose \& Meyer, 2002).

Finally, assistive technology requires teachers to go beyond putting a given technology (e.g., a digital textbook or portable reading device) in front of a student to understand its application to improve learning. Some years ago, Cruickshank (1977) posited that nothing is more harmful to children than lost opportunities to learn. While past-to-present opinion not surprisingly varies regarding the proper course of action, we can ill afford to languish in the dark or otherwise fail to keep our promise to assure a quality education to children and adolescents with disabilities.

$$
* * *
$$

\section{Outlook on Special Education Practice Richard Van Acker}

\section{INEFFECTIVE PRACTICES}

Over the years the field of special education has made some remarkable advances. Today a burgeoning number of proven effective practices and procedures are positively influencing the social and academic outcomes of persons with disabilities. Our field has benefited greatly from the work of many dedicated and talented researchers and practitioners (see Winzer, 1993, for a historical review of special education). Nevertheless, we still need to develop more effective and efficient approaches to prevention/intervention in special education.

The expansion of educational "best practices" has not always relied on empirically validated procedures and practices. All too often, new practices are introduced with great fanfare and are propagated widely on the basis of political or economic expediency. Many new approaches seem to have a great deal of conceptual or logical validity, garnering the support of educators and the general public alike despite a dearth of empirical support.

The so-called bandwagon effect surrounding many of these interventions propels them into common use. We are reminded that Burton Blatt once observed that bandwagons also go to funerals. Indeed, over time many popular interventions have failed to demonstrate any real educational or therapeutic value, and some even have been found to be harmful.

For example, Lipsey (1992) reported that an estimated $29 \%$ of controlled intervention studies targeting adolescent problem behavior demonstrated negative effects. The longstanding practice of wholesale adoption of educational practices prior to empirical validation is problematic for a number of reasons. There is the ethical dilemma of subjecting students to educational practices that may have no benefit or, worse, that actually cause harm. Given the limited time that students are available for instruction, the consequences associated with ineffective instruction should be a serious concern. As Sugai (1998) put it, time is unforgiving as it relates to the fate of children with disabilities. Accordingly, we cannot allow intellectual alchemists to turn personal beliefs into scientific truths at the expense of quality instruction (Gable, 2004).

Be it past or present, we have good reason to fear that ineffective practices will displace proven effective approaches to instruction, as we witnessed when whole language instruction was introduced in preference to the more effective phonics approach to reading (Chall, 1997). Another concern relates to the time and cost of reeducating administrators and teachers who previously were taught to use these ineffective strategies. In addition, there is the problem of informing students and their families that practices they may have actively supported are not effective and the school cannot employ them any longer. Finally, the propagation of ineffective interventions can do grave harm to the credibility of the field (Mostert \& Crockett, 2000).

As a field, something is to be learned from distinguishing among effective and ineffective interventions-both of which are present in special and general education classrooms. As Cullinan, Epstein, and Lloyd (1991) asserted, failing to evaluate the efficacy of an intervention creates a climate in which ineffective strategies remain in practice and potentially effective ones become suspect or are discarded because they lack strong empirical support. We will offer a few examples of empirically questionable or ineffective educational practices that were-and sometimes continue to be-actively implemented in their original or some newly adapted form within many school settings.

\section{Patterning}

In the 1960s, Doman (1994) and Delacato (1974) introduced a treatment based on neurophysiological restraining termed "patterning." Their approach was predicated on the belief that the functioning of a damaged central nervous system could be improved by stimulating specific sensory inputs, thereby eliciting specific motor output patterns (Sieben, 1977). Patterning required parents (or other caregivers) to manipulate the child's body in an imitation of specified developmental movements (e.g., crawling or creeping movements). Doman and Delacato claimed that patterning of the central nervous system could (a) enhance 
intellectual ability in persons with brain damage; (b) prevent and/or improve speech, communication, and visual and reading disabilities; and (c) prevent or treat deviant behavior (Sieben, 1977).

Over time, many parents and educators became increasingly concerned over the demanding requirements of the "patterning regime" and the lack of perceived results. Empirical research failed to support this practice, and the American Academy of Pediatrics concluded the following:

\begin{abstract}
Based on past and current analyses, studies, and reports, we must conclude that patterning treatment offers no special merit, that the claims of its advocates are unproven, and that the demands on families are so great that in some cases there may be harm in its use. (1999, p. 1150)
\end{abstract}

Today, a number of yet-to-be validated treatment procedures using neurophysiological restraining reminiscent of patterning are being propagated under terms such as applied kinesiology, optometric visual training, and cerebellar-vestibular remediation (Silver, 1987).

\section{Cell Therapy}

Another treatment introduced in the 1960s was cell therapy. Franz Schmid (in Fackelmann, 1990), a German physician, proposed intramuscular injections of a solution containing freeze-dried fetal sheep or rabbit cells as a means of promoting improved social and intellectual development in individuals with Down syndrome. In a survey of the parents of 116 children who had received cell therapy, Baumeister and Hamlett (1986) reported that $71 \%$ of the parents reported improved learning ability in their children (reported in Fackelmann, 1990). The results of this study relied upon parent self-reports rather than the objective evaluation of student outcomes.

In a similar survey of 190 children with Down syndrome, Van Dyke and Lange (VanDyke, Lange, Heide, van Duyne, \& Soucek, 1990) found that children who had received cell therapy displayed "... no statistically significant differences for any of the 18 social, developmental, or growth variables measured" (p. 116) when compared to matched controls. Subsequently, the National Institute of Child Health and Human Development put forth a statement stating that "no evidence exists that cell therapy is an effective treatment for Down syndrome at this time" (Fackelman, 1990, p. 168). Still, cell therapy is widely practiced much the same way as when it was first introduced.

More recent advances in our understanding of cell biology have led to new areas of investigation, including human stem cell research. This line of inquiry has shown significant promise in disorders such as cerebral palsy, multiple sclerosis, and for post-stroke patients (Olson, 2005).

\section{Dietary Therapies}

Over the past several decades, a number of dietary, food supplement, and megavitamin treatments have been promoted to treat various disorders. Numerous parent accounts are suggesting that their children with disabilities, such as autism, ADHD, behavior disorders, and learning disabilities, appear to react to various food items. Food allergies and/or problems in metabolizing various proteins have been hypothesized as the problem (Sieben, 1977). A variety of special diets such as the Feingold Diet (Feingold, 1977, 1996) and the Gluten Free Casein Free Diet (Knivsberg, Reichelt, Hoien, \& Nodland, 2003) have been reported to show positive results. Other researchers, however, have failed to replicate these positive results, and most experts believe that the positive results identified earlier are seen in only a small number of individuals (Adams, 1981; Kavale \& Forness, 1983; Mattes, 1983). Despite the lack of empirical evidence to support the efficacy of such dietary interventions, many parents continue to rely on these treatment options.

In turning to another treatment that has gained a measure of acceptance, Cook and Stevens (1987) suggested that Candida Albicans yeast, which is found in the interior membranes of humans, is responsible for many maladaptive and disruptive responses in persons with disabilities. These researchers suggested that the normal functioning of these yeast cells was disturbed in persons with various disorders, causing the production of a toxin that affected the organs and systems in the body (e.g., immune, endocrine, and nervous systems). Like the Feingold Diet, differing levels of Candida Albicans yeast have been found to have an influence on a small number of children and youth; however, the connection between the level of this yeast and behavior is far from supported (Seiben, 1977).

As early as 1952, massive doses of niacin and ascorbic acid were prescribed to adult patients with schizophrenia (Rimland, 1973). Since that time, some have advocated megavitamin therapy - the consumption of up to 1,000 times the usual daily requirement of one or more vitamins-to remedy a variety of disorders including mental retardation, psychosis, autism, ADHD, dyslexia, learning disabilities, and behavioral disorders (Rimland \& Larson, 1983; Sieben, 1977). Again, research on megavitamin therapy has failed to support its effectiveness (Sieben, 1977). Moreover, many physicians have voiced concern about the potential for toxicity of massive doses of some vitamins. Indeed, the Academy of Pediatrics concluded that clinical results have failed to support "megavitamin therapy as a treatment for learning disabilities and psychosis in children, including autism" (Shaywitz, Siegal, \& Pearson, 1977, p. 1750). 


\section{Facilitated Communication}

Perhaps the most well known example of a special educational intervention that gained widespread popularity only to be discredited later is facilitated communication (FC). Simply put, facilitated communication is a method of augmentative or alternative communication that involves supporting or "facilitating" the arm or hand of a communicatively impaired person while he or she types out a message on a computer keyboard or other device. FC is predicated on the mistaken assumption that many individuals with severe communicative disorders (e.g., those with autism or severe and profound mental retardation) have a level of "undisclosed literacy" that can be "tapped" through this procedure.

In the early 1990s, some in the field heralded FC as a way to unlock the thoughts, ideas, and desires of many individuals with severe communicative disorders (Biklen, 1993; Crossley, 1992). Subsequently, facilitated communication procedures were taught in many colleges of education and speech therapy programs across the United States. Closer examination of facilitated communication and explorations of FC successes, however, yielded scant empirical support for the practice. Only a few individuals who were reported to use FC were shown to be entering their messages "independently" (Beukelman \& Mirenda, 1998). When the "facilitator" and the student were provided independent questions or directions, in the vast majority of cases, the message entered on the keyboard related to that of the "facilitator" rather than the individual being facilitated (Bligh \& Kupperman, 1993; Mostert, 2001; National Research Council, 2001; Wheeler, 1993).

The American Psychological Association (1994) adopted a resolution regarding $\mathrm{FC}$ in which the APA concluded that it "... is a controversial and unproved communication procedure with no scientifically demonstrated support for its efficacy" (p. 1). Nevertheless, FC continues to garner support of some in the educational community (Gerlach, 1993) and to stimulate other practices that incorporate aspects of FC.

\section{Rapid Prompting Method}

An example of these practices is the rapid prompting method (RPM). RPM is an instructional technique designed to develop academic and communication skills in individuals with severe autism (CBS Broadcasting, 2003). This intervention program was designed by Soma Mukhopadhyay, a teacher and a mother of a child with autism. RPM elicits responses from persons with autism through a combination of intensive verbal, auditory, visual, and tactile prompts. As in FC, the RPM employs the facilitation of the person's hand or arm as he or she types, points, or writes the responses. To date, PPM has yet to be empirically validated.

\section{Sensory Integration Therapy}

Educators and occupational therapists practice sensory integration therapy in many schools today. The theory supporting these practices proposes that some individuals demonstrate significant disorganization as the brain attempts to locate, sort, and order the incoming sensations in order to form perceptions and/or to act on these sensations in the form of an adaptive response (Ayers, 1979). The theory suggests that these individuals are challenged in their efforts to filter, inhibit, organize, and/or interpret the sensory inputs. In turn, the individual cannot respond in an adaptive manner to the sensory input experienced.

Sensory integration therapy is a sensorimotor treatment technique that responds to specific sensory integration dysfunctions observed in the individual. That is, treatment and treatment goals are deduced logically and related to the nature of the sensory integration dysfunction detected. Assessment of dysfunction employs the trained, structured observation of postural reactions, eye-hand usage and coordination (Vezie, 1975). Sensory integration therapy involves guiding the child through a sequence of activities (the sensory diet) designed to challenge his or her ability to respond appropriately to sensory input or the make a successful, organized adaptive response. For example, for children displaying tactile imbalances, activities might include touching, brushing, or rubbing.

Research on the efficacy of sensory integration therapy has yielded mixed results (Baranek, 2002). Even the studies that suggest immediate improvement on measures of sensorimotor functioning fail to demonstrate notable improvement in academic learning or long-term sensorimotor functioning (Dawson \& Watling, 2000; Din \& Lodato, 2001; Mauer, 1999). Notwithstanding the dearth of empirical support, sensory integration therapy still is practiced in schools in forms such as sensory integration therapy, sensory stimulation therapy, and auditory integration training.

\section{Iatrogenic Effects}

Some compelling evidence suggests that the context of intervention can impact significantly the effectiveness of an intervention. For example, numerous reports indicate that placing high-risk youth together in homogeneous groups for treatment may result in harmful, or iatrogenic, effects. Indeed, in studies conducted by Dishion, McCord, and Poulin (1999), youth who were provided peer-group intervention displayed more adolescent problem behaviors and negative life outcomes in adulthood than their counterparts in the control group. Dishion et al. asserted that for high-risk youth, homogeneous aggregation can result in the inadvertent reinforcement of problem behavior by like peers. Aggregation of these high-risk youth affords them what 
essentially is a "deviance training" situation in which peers respond positively to rule-breaking behavior.

Similar iatrogenic effects have been reported by other researchers for peer-group interventions designed to address antisocial behavior (Cho, Hallfors, \& Sanchez, 2005), sexual promiscuity (Patterson, Dishion, \& Yoerger, 2000), alcohol and substance abuse (Moos, 2005; Werch \& Owen, 2002), and low academic achievement (Catterall, 1987). Iatrogenic effects also have been reported for residential placement of youth referred for treatment of antisocial behavior (Powell \& Lochman, 2004). These iatrogenic effects are more pronounced for groups of younger adolescents (aged 10 through 16), and older adolescents seem to be less effected (Eggert, Thompson, Herting, Nicholas, \& Dicker, 1994). These findings may hold significance for schools that typically employ discipline practices that cluster high-risk youth together (e.g., detention and in-school suspension programs).

\section{Positive Behavior Interventions and Supports and Multimodal Programs}

An additional factor that must be taken into consideration when developing a program or procedure is the demand that an intervention places upon those responsible for its delivery. Even though the volume of research on what constitutes effective classroom practices has grown tremendously over the past 10 years (Gable, 2003), many of these practices have not been well received and have failed to "map onto the culture or realities of the school setting." For example, one of the most widely researched and proven effective programs for addressing the issue of schoolwide discipline is positive behavior interventions and supports (PBIS) (Sugai $\&$ Horner, 2002). Unfortunately, the need to dedicate approximately 3 to 5 years to initiate the program with a minimum $80 \%$ "buy-in" from the faculty and staff has prompted many school administrators and faculty members to simply refuse to consider this approach. Moreover, schools that do attempt to put PBIS into practice have a high attrition rate (Muller, 2002).

A number of multimodal programs that have been shown to be effective in dealing with student antisocial behavior have failed to be adopted within the public schools (Flay \& Collins, 2005; Foster \& Fang, 2004). Despite the strong empirical support for a growing number of intervention options, the politics of many schools, coupled with the high rate of staff and administrative turnover, thwart efforts to adopt long-term, systemwide programs. In addition, there is the issue of treatment acceptability as it relates to both the person delivering (e.g., the classroom teacher) and the person receiving the treatment (e.g., the student). For adults, acceptance often hinges on the perceived practicality and effectiveness, coupled with a sense of competency in applying the strategy. For students, acceptance may depend on the kind and amount of attention attached to the treatment.

Finally, for various other reasons, even proven effective treatments have failed to gain acceptance. For instance, over the past several decades, special education has abandoned a number of aversive procedures (e.g., contingent electric shock) despite empirical support for them (Romanczyk \& Goren, 1975). In these instances, issues surrounding the ethical and humane care of persons with disabilities proved to be a powerful force with regard to implementation of interventions and treatments.

\section{"Best Practices" Research}

There is general recognition of the need for continued research related to what constitutes "best practices" in special education. This is an ongoing process that builds upon the work of those who came before us. Program development also requires vision and creativity-willingness to risk and to go beyond commonly held beliefs. At the same time, we have yet to address a number of theoretical, moral, and practical issues. If we are to move forward, we must dedicate ourselves to working tirelessly to develop treatments and procedures that are empirically validated as effective and that also take into consideration the context of care. These practices

1. must be reasonable and acceptable to those responsible for their implementation,

2. should "fit" with the realities of the context in which they are to be applied, and

3. must be acceptable to those for whom they are intended.

Recent legislation. including Public Law 107-110, No Child Left Behind, and the Education Sciences Reform Act of 2002, stipulates that educators must use "scientifically based interventions" and calls for the "testing of educational practices" in a manner similar to that used by medical scientists "to assess the effectiveness of medications, therapies, and the like" (U. S. Department of Education, 2002, p 12). But we have to move beyond the simple examination of positive outcomes when exploring the effectiveness of an educational or therapeutic intervention. Researchers should attempt to study mechanisms of change, contextual variables that may effect treatment outcomes, the distinction between statistical and social or clinical significance of the outcomes, dissemination factors (e.g., ease of implementation), and any iatrogenic effects associated with the treatment (Follette \& Beitz, 2003).

Educational researchers must take the time to test their interventions and to identify both the costs and the benefits 
associated with their use prior to their widespread dissemination. We must not continue to subject students and their families to unsubstantiated practices, nor can we afford to engage in activities in which we educate teachers to deliver services that have no benefit or that can harm their students. Educators must be prepared to examine any new educational intervention, approach, or strategy critically on the basis of what they know and what they can verify empirically as effective.

We have the responsibility to deliver empirically validated services that have been shown to be effective for the type of students to whom we wish to apply the procedure. Ignorance of the facts and adherence to vague philosophical notions (Gable, 2004; Polsgrove, 2003) has too long had a detrimental effect on the life changes of students with disabilities. We know all too well that, for many of these students, second chances are in short supply.

$$
* * *
$$

\section{Concluding Thoughts: The Future as Problem-Saturated or Solution-Centered?}

In these two views, Hardman and Van Acker have examined critically past-to- present accomplishments, identified persistent and unresolved challenges, offered their personal perspectives, and, finally, made recommendations on ways to plot a course of action that ensures a brighter future for our field. As stated at the outset, careful analysis of their thoughts, as well as those of previous prognosticators, led us to conclude that some issues have been repeatedly revisited. We distilled the most common and repetitive among them into six aforementioned themes:
1. Willful ignorance
2. Shots in the dark
3. Broken promises
4. Problematic paradigms
5. Vacuums of popular opinion
6. Detrimental effects

\section{WILLFUL IGNORANCE}

Kauffman (1999b) posited that one present-day characteristic of special education is the professional culture's woeful ignorance of the past. He cautioned that some of the reform literature was distorted; devoid of lessons that preP.L. 94-142 history of special education taught us-that without a separate educational system, students with exceptionalities would not receive access to specialized schooling. His warning could not be clearer: Our failure to acknowledge the past would condemn us to repeat mistakes of policy and practice in the future.
Others (see Cronis \& Ellis, 2000; Gable, 2004; Mostert \& Crockett, 2000; Nelson 2003; Polsgrove, 2003; Zigmond, 2001) also have discussed the refusal of many in the field to accept the myriad problems associated with contemporary service delivery options, such as resource and inclusion. These decade-old discussions lend further support to the importance of considering the impact of willful ignorance. The concept of willful ignorance refers to the failure of "actors" (i.e., professionals) to recognize something that is apparent to even the most casual observer (Charlow, 1992).

In a law review, Charlow explored whether willful ignorance amounts to a criminally culpable state of mind. He argued that even though "actors" are not technically culpable under the most generally accepted notions of this term, they are responsible nonetheless for the criminal conduct that has occurred. Charlow offered the example of the CIA director who did nothing about the Iran-Contra scandal. Presumably, the director chose to ignore it so as to support his position.

In applying the notion of willful ignorance to contemporary special education policy and practice, the widespread practice of inclusion seems especially relevant. If legislative mandates (i.e., IDEA and NCLB) ensure students with exceptionalities a FAPE in addition to providing a guarantee for AYP, and professionals offer scientifically sound evidence (see Kavale \& Forness, 2000; Schumm \& Vaughn, 1991; Zigmond \& Baker, 1995) that verifies the violation of these tenets - which technically constitutes a criminal actit is a violation of federal law. As scholars and advocates, we must assume some of the responsibility when it is apparent to parents, teachers, and students that these practices are not having a positive effect.

Hardman (in this article) offers another example of willful ignorance that links past-to-present legislation: He questions whether a standards-based system that must be mastered within a predetermined and finite amount of time is compatible with what we know about the characteristics of effective special education practice. Clearly, the answer to even a casual observer is "no." Yet, short of writing articles in scholarly journals (preaching to the choir) and engaging in limited advocacy efforts, we do too little to raise awareness and put an end to practices that clearly are not in the best interest of students with exceptionalities.

\section{SHOTS IN THE DARK}

"Shots in the dark" is the term used to describe the widespread promotion of unsubstantiated behavior intervention and instructional methods in special education. In the past forecasting literature, numerous authors have identified this issue as highly problematic (Brigham, Gustashaw, \& Brigham, 2004; Kauffman, 1994; Kavale \& Mostert, 2003; 
McGrath, Johns, \& Mathur, 2004; Mostert \& Crockett, 2000; Zigmond, 2001). The unanimous conclusion was that, more often than not, special education professionals employ methodology that lacks a sound scientific underfooting.

The reasons that unsubstantiated methods take hold within the educational community have not been well understood. Sasso (2001) asserts that professionals propagate unfounded approaches not to advance the field of knowledge or to advocate for quality services for students with exceptionalities but, rather, to shamelessly promote themselves and elevate their stature within the intellectual community. The proponents of many past-to-present approaches have ignored the critical role of informed scientific practice; instead, they have deferred to an internally driven need for significance that overrides their commitment to pursue scholarly enlightenment.

Brigham and his colleagues offer another opinion-that advocacy guides special education instead of science (see Brigham, Gustashaw, \& Brigham, 2004). Regardless of why these unsubstantiated approaches take hold, leaders in the field must demand an end to such unscientific pursuits in both the scholarly and public presses.

Moving beyond why these misguided approaches surface, Van Acker, in this article, offers numerous examples of past-to-present interventions that lack scientific support. He urges us to be mindful that embracing a simple examination of positive outcomes may not be enough, as results often are colored by ease of strategy implementation, iatrogenic effects, and clinically rather than socially significant outcomes.

Few would disagree that the ultimate price for our "shots in the dark" is the squandering of precious opportunities for children to learn. As stated previously, Cruickshank (1977) posited that nothing is more deleterious to children. As scholars, we must undertake only those activities that ensure accomplishments to serve "the greater good." In the medical community, when a physician fails to serve the greater good and employs a shot-in-the-dark approach to treatment, the most likely outcome is loss of licensure, a malpractice suit, or both. In contrast, what sanctions are imposed within the educational community? mediation? due process? Unfortunately, the results of these actions often depend on geography and parental access to legal or educational resources; both of which are compromised seriously when families live in poverty - a circumstance that accounts for the largest constituency served by special education services.

\section{BROKEN PROMISES}

The broken promises theme refers to the inherent gaps between disability-related legislation and actual special education practice. As several authorities (Cronis \& Ellis, 2000;
Kauffman, 1994, 1999b; Webber \& Scheuermann, 1997) have pointed out, the original EHCA established a number of guarantees to students with exceptionalities and their families. Three decades and numerous reauthorizations later, these guarantees remain elusive. Chief among them is the promise of individualization (Gerber, 1995; Kauffman, 1994, 1999b; Kavale \& Mostart, 2003; Zigmond, 2001). Gerber (1995) has argued that many within the educational community have adopted the "all means all" rhetoric in place of the "each means each" mandate.

Lack of a precise definition in federal policy makes misinterpretation all too common. Also threatened, because of loose definitions, are protections associated with zero reject, LRE, and eligibility (see Cronis \& Ellis, 2000; Kaufmann, 1999b; Webber \& Scheuermann, 1997). The magnitude of the cost of misinterpretations is well documented in the accumulated literature, as reflected by the widespread provision of undifferentiated services for students with exceptionalities (see Kavale \& Forness, 2000; Schumm \& Vaughn, 1991; Zigmond \& Baker, 1995).

Hardman (in this article) offers another example of broken promises stemming from misalignment rather than misinterpretation in relationship to the Goals 2000: Educate America Act. Even after years of supporting research, states have not embraced opportunity-to-learn (OTL) standards set forth in this Act. Hardman questions whether local education agencies have sufficient quality resources, knowledge of best practices, and the proper infrastructure at each level of the educational system to ensure each student an appropriate opportunity to learn. Across time, numerous studies have shown that students with disabilities are offered fewer opportunities to respond, give fewer correct responses and, in turn, receive fewer praise statements.

If students with exceptionalities continue to receive limited opportunities to learn, can they receive a FAPE? Moreover, can schools meet the common standards expected by NCLB (2001)? The obvious responses are "no" and "no." Unfortunately, these all-too- common misalignments in federal and state policies impede the spirit as well as the letter of the laws, which in turn reduces many of them to a merely symbolic rather than substantive level.

\section{PROBLEMATIC PARADIGMS}

Over the past several decades, many authors have examined critically the "paradigm wars" and their impact on special education policy and practice (see Gable, 2004; Kauffman, 1999b; Polsgrove, 2003; Rueda, 2005; Sasso, 2001). One paradigm, frequently referred to as the progressivists' view, stems from doctrines in postmodernism and cultural relativism (Reid, Robinson, \& Bunsen, 1995). Postmodern theorists assert that alternative paradigms are needed to 
expand the boundaries of special education knowledge hindered by a narrow empirical perspective. By contrast, the traditionalists' stance is rooted firmly in scientific objectivity or positivistic ways of knowing.

The current literature is replete with widespread, often continuous debate between these two adversarial groups. Unfortunately, the divisiveness does not end in the scholarly discourse. These conflicting value and belief systems have trickled down to fuel parents' and practitioners' confusion regarding what constitutes best practice.

Gable (2004) ascertained that this lack of a unified theoretical framework contradicts our desire to improve outcomes for students with exceptionalities and undermines our efforts to provide quality special education services. For these reasons, Gable (2004) and Kauffman (1994) have called on leaders in special education to construct strong philosophical foundations, to generate goals that guide the profession, and to delineate a plan that addresses exactly how we might achieve them. Neither calls for the elimination of rival philosophies. Instead, they welcome alternative philosophical orientations and set forth the challenge for each to be anchored in rigor and substance. Sasso (2001) concurred and also acknowledged that science is not the only way to obtain answers about special education. He also cautioned professionals that activism and analysis are unique pursuits that lead to differing outcomes-the former of which are more predetermined than the latter.

Hardman and Van Acker (in this article) do not address explicitly the theme of problematic paradigms, yet it is inferred in their underlying messages. In Hardman's piece, one can infer that vague philosophical notions contribute to the adoption of misguided and misaligned policy. In Van Acker's discussion on future prevention/intervention practices, he uses the example of widescale adoption of whole language approaches to remind us that we have good reason to fear that ineffective practices will displace proven effective approaches. Why are unsubstantiated practices accepted so widely with too little proof? Part of the problem is that we have yet to establish a generally acceptable conceptual framework (Gable, 2004).

\section{VACUUMS OF POPULAR OPINION}

Over the years, various prognosticators have written about the impact of popular opinion on special education policy and practice (Gable 2003; Kauffman, 1994, 1999b; Nelson, 2003; Polsgrove, 2003). Unfortunately, the reality is that special education is a subcomponent of the general education, which is a public system. Indeed, our system of public education is just that - public - and thereby at the mercy and whim of popular opinion. Also, we must recognize that special education services are directed toward the minority portion of the majority public school population. Thus, as special educators, we are at a distinct disadvantage. We are at the public's mercy, and also charged with the monumental task of convincing the community-at-large that "our kids" are worth the educational investment. To say that this is not an easy task would be an understatement.

Take, for example, an article entitled, "How Special is Special Education?" authored by Finn (1996) and posted on the Thomas B. Fordham Foundation website. In this piece, Finn argues that contemporary special education mandates create a double standard with regard to discipline. The crux of his argument is based on a quote he offers from a "respected" Fairfax County school superintendent: "Any student who is classified as disabled is now literally able to get away with anything" (p. 2).

School discipline is a highly inflammatory subject about which the general public harbors strong and often misguided opinions. Current sentiment largely reflects a "get tough" philosophy that has had a powerful influence on education policy and practice, triggering numerous "zero tolerance" practices that impact negatively outcomes for students with exceptionalities.

Brigham, Gustashaw, and Brigham (2004) assert that advocacy efforts based on popular opinion can be effective. They speculate that this "mode of thought" can be critical to shaping the field of special education in ways that ensure access to public education for students with exceptionalities. They argue further that these same tactics may be applied to preserve present-day practice and impede the growth of our profession. We agree.

For his part, Hardman (in this article) expressed concern about the danger inherent in succumbing to popular opinion with regard to future special education policy. His assertion that there is a dearth of empirical evidence to support the adoption of standards-driven policy deserves our attention. Finally, Hardman reminds us that the educational achievements of students with exceptionalities often are linked directly to prevailing educational policy. It stands to reason that if contemporary policy lacks substance, student outcomes will be seriously compromised.

\section{DETRIMENTAL EFFECTS}

The most fundamental principle of any profession is to do no harm. Accordingly, the most troubling issue regarding the past-to-present special education practices is the extent to which we rely on interventions that have been proven to be harmful. Previous authors (Forness \& Kavale, 2001; Kauffman, 1999b; Kavale \& Mostart, 2003; Mainzer, Deshler, Coleman, Kozleski, \& Rodriguez-Walling, 2003; Polsgrove, 2003; Webber \& Scheuermann, 1997) have addressed this issue and called for reform in special education. 
Van Acker (in this article) observes that one harmful effect involves using interventions that have little or no educational worth-the net result of which is the irreparable loss of critical instructional time. The other harmful effect entails use of interventions that have a demonstrated negative effect. Professionals in the field have a moral obligation to drive a stake through the heart of practices that do more harm than good. In that regard, Mostert and Crockett (2000) have enumerated three critical components of informed practice: "what has worked, what has not, and the ability to tell the difference" (p. 142). We concur-and offer one addition: "... and a commitment to do no harm."

Some might argue that the themes we have discussed are problem-focused and that the views supporting them are extreme. To the contrary, if we are to move the field in a positive direction, we must acknowledge the problems of the past and tackle these tough and often unpleasant issues in substantive ways. An extensive review of past forecasting literature leads us to conclude that not much has changed in a decade of discussion on the future of special education.

We offer the following illustration: Fuchs and Fuchs (in Helgason, 2003) suggested that we consider

\begin{abstract}
....an urban third-grade classroom of 34 children, a third of whom live in poverty. Six live with grandparents. Three are in foster care. Two have been physically or sexually abused. Five come from homes in which a language other than English is spoken. There is a five-grade spread in reading achievement. Only six read at or above their grade level. Ten are more than two grade levels below target. And three of the 34 have been certified as having learning disabilities. (p.16)
\end{abstract}

If we address the future in the same manner that we have responded in the past, can we reasonably assume that a brighter future awaits students with disabilities?

Some authors (e.g., Cronis \& Ellis, 2000) suggest that the future of special education is one of evolution, not revolution. Our position differs. We believe that the path to a brighter future is one paved by a revolution. An all-out declaration of war on what we know doesn't work in special education. Let the revolution begin.

\section{REFERENCES}

Adams, W. (1981). Lack of behavioral effects from Feingold diet violations. Perceptual and Motor Skills, 52, 307-313.

Albrecht, S. F., \& Joles, C. (2003). Accountability and access to opportunity: Mutually exclusive tenets under a high-stakes testing mandate. Preventing School Failure, 47, 86-91.

American Academy of Pediatrics. (1999). The treatment of neurologically impaired children using patterning. Pediatrics, 104, 1149-1151.

American Psychological Association. (1994). Resolution on facilitated communication by the American Psychological Association. Downloaded May 1, 2005, at http:/soeweb.syr.edu/thefci/apafc.htm
Ayers, A. J. (1979). Sensory integration and the child. Los Angeles: Western Psychological Services.

Baranek, G. T. (2002). Efficacy of sensory and motor interventions in children with autism. Journal of Autism and Developmental Disorders, 32, 397-422.

Baumeister, A. A., \& Hamlett, C. L. (1986). A national survey of statesponsored programs to prevent fetal alcohol syndrome. Mental Retardation, 24, 169-173.

Bentler, P. M., \& Speckart, G. (1981). Attitudes "cause" behavior: A structural equation analysis. Journal of Personality and Social Psychology, 40, 226-238.

Beukelman, D. R., \& Mirenda, P. (1998). Augmentative and alternative communication: Management of severe communication disorders in children and adults (2nd ed.). Baltimore: Paul $\mathrm{H}$. Brookes.

Biklen, D. (1993). Communication unbound: How facilitated communication is challenging the views of autism and ability/disability. New York: Teacher's College Press.

Billingsley, F. F., Liberty, K. A., \& White, O. R. (1994). The technology of instruction. In E. C. Cipani \& F. Spooner (Eds.), Curricular and instructional approaches for persons with severe disabilities (pp. 81-116). Boston: Allyn and Bacon.

Bligh, S., \& Kupperman, P. (1993). Evaluation procedure for determining the source of the communication in facilitated communication accepted in a court case. Journal of Autism and Developmental Disorders, 23, 553-557.

Brigham, F. J., Gustashaw, W. E., III, \& Brigham, M. S. P. (2004). Scientific practice and the tradition of advocacy in special education. Journal of Learning Disabilities, 37, 200-206.

Bryan, T. (1999). Reflections on a research career: It ain't over till it's over. Exceptional Children, 65, 438-447.

Carnine, D. (2000). Why education experts resist effective practices (And what it would take to make education more like medicine). Washington, DC: Thomas Fordham Foundation.

Catterall, J. S. (1987). An intensive group counseling drop-out prevention intervention: Some cautions on isolating at-risk adolescents within high schools. American Educational Research Journal, 24, 521-540.

CBS Broadcasting, Inc. (2003). 60 Minutes: Breaking the silence. Television broadcast July 16, 2003.

Chall, J. S. (1997). Are reading methods changing again? Annals of Dyslexia, 47, 257-263.

Charlow, R. (1992). Willful ignorance and criminal culpability. Texas Law Review, 70, 1351.

Cho, H., Hallfors, D. D., \& Sanchez, V. (2005). Evaluation of a high school peer group intervention for at-risk youth. Journal of Abnormal Child Psychology, 33, 363-374.

Cook, W. G., \& Stevens, L. (1987). Solving the puzzle of your hard-toraise child. New York: Random House.

Cronis, T. G., \& Ellis, D. N. (2000). Issues facing special educators in the new millennium. Education, 120, 639-648.

Crossley, R. (1992). Getting the words out: Case studies in facilitated communication training. Topics in Language Disorders, 12, 29-45.

Cruickshank, W. M. (1977). Myths and realities in learning disabilities. Journal of Learning Disabilities, 10, 51-58.

Cullinan, D., Epstein, M. H., \& Lloyd, J. W. (1991). Evaluation of conceptual models of behavior disorders. Behavioral Disorders, 16, 148-157. 
Dawson, G., \& Watling, R. (2000). Interventions to facilitate auditory, visual, and motor integration in autism: A review of the evidence. Journal of Autism and Developmental Disorders, 30, 415-421.

Delacato, C. H. (1974). The ultimate stranger: The autistic child. New York: Doubleday.

Din, F. S., \& Lodato, D. M. (2001). The effect of sensory integration treatment on children with multiple disabilities. Focus on Autism and Other Developmental Disabilities, 16, 12-16.

Dishion, T. J., McCord, J., \& Poulin, F. (1999). When interventions harm: Peer groups and problem behavior. American Psychologist, $54,755-764$.

Doman, G. (1994). What to do about your brain-injured child. Garden City Park, NY: Avery Publishing Group.

Eggert, L. L., Thompson, E. A., Herting, J. R., Nicholas, L. J., \& Dicker, B. G. (1994). Preventing adolescent drug abuse and high school drop-out through an intensive school-based social network development program. American Journal of Health Promotion, 8, 202-215.

Elbaum, B. E., Vaughn, S., Hughes, M., \& Moody, S. W. (2000). How effective are one-to-one tutoring programs in reading for elementary students at risk for reading failure? Journal of Educational Psychology, 92, 605-619.

Fackelmann, K. (1990). New hope of false promise: Study shows futility of alternative Down syndrome treatment. Science News, March 17, 168-169.

Feingold, B. F. (1977). Food additives and hyperkinesis: Dr. Feingold replies. Journal of Learning Disabilities, 10, 122-124.

Feingold, B. F. (1996). Why your child is hyperactive. New York: Random House.

Finn, C. E., Jr. (1996). How special is special education? Retrieved September 10, 2005, from http://www.edexcellence.net/foundation/publication/publication.cfm?id=197

Flay, B., \& Collins, L. M. (2005). Historical review of school-based randomized trials for evaluating problem behavior prevention programs. Annals of the American Academy of Political and Social Science, 599, 115-146.

Florian, L., \& Pullin, D. (2000). Defining difference: A comparative perspective on legal and policy in education reform and special educational needs. In M. J. McLaughlin \& M. Rouse (Eds.), Special education and school reform in the United States and Britain (pp. 11-37). London: Routledge.

Follette, W. C., \& Beitz, K. (2003). Adding a more rigorous scientific agenda to the empirically supported treatment movement. Behavior Modification, 27, 369-386.

Forness, S. R., \& Kavale, K. A. (2001). Reflections on the future of prevention. Preventing School Failure, 45, 75-81.

Foster, E. M., \& Fang, G. Y. (2004) Alternative methods for handling attrition: An illustration using data from the Fast Track Evaluation. Evaluation Review, 28, 434-464.

Gable, R. A. (2003). Like it is: Thoughts on the career of Lewis Polsgrove. Behavioral Disorders, 28, 227-228.

Gable, R. A. (2004). Hard times and an uncertain future: Issues that confront the field of emotional/behavioral disorders. Education and Treatment of Children, 27, 341-352.

Gerber, M. M. (1995). Inclusion at the high-water mark? Some thoughts on Zigmond and Baker's case studies of inclusive educational programs. Journal of Special Education, 29, 181-191.

Gerlach, E. (1993). Autism training guide. Eugene, OR: Four Leaf Press.
Hardman, M. L., McDonnell, J., \& Welch, M. (1997). Future perspectives on the Individuals with Disabilities Education Act. Journal of the Association for Persons with Severe Handicaps, 22(2), 61-76.

Hardman, M. L., \& Nagle, K. (2004). Policy issues. In A. McCray, H. Rieth. \& P. Sindelar (Eds.), Contemporary issues in special education: Access, diversity, and accountability. Boston: Allyn and Bacon.

Helgason, J. (2003). No child left behind? Peabody Reflector, 7l(2), 12-17.

Hendrick Hudson District Board of Education v. Rowley, 458 U.S. 176 (1982).

Huefner, D. S. (1991). Judicial review of the special education program requirements under the Education for All Handicapped Children Act: Where have we been and where should we be going? Harvard Journal of Law and Public Policy, 14, 483-516.

Huefner, D. S. (2000). Getting comfortable with special education law: A framework for working with children with disabilities. Norwood, MA: Christopher Gordon Publishers.

Ingels, S. J. (1996). Sample exclusion in NELS: 88: Characteristics of base year ineligible students; changes in eligibility status after four years (NCES Technical Report 96-723). Washington, DC: U.S. Department of Education, Office of Educational Research and Improvement.

Kauffman, J. M. (1994). Places of change: Special education's power and identity in an era of educational reform. Journal of Learning Disabilities, 27, 610-618.

Kauffman, J. M. (1999a). Commentary: Today's special education and its messages for tomorrow. Journal of Special Education, 32, 244-254.

Kauffman, J. M. (1999b). The special education story: Obituary, accident report, conversion experience, reincarnation, or none of the above? Exceptionality, 8, 61-71.

Kavale, K. A., \& Forness, S. R. (2000). History, rhetoric, and reality: Analysis of the inclusion debate. Remedial and Special Education, 21, 279-296.

Kavale, K. A., \& Forness, S. R. (1983). Hyperactivity and diet treatment: A meta-analysis of the Feingold hypothesis. Journal of Learning Disabilities, 16, 324-330.

Kavale, K. A., \& Mostert, M. P. (2003). Rivers of ideology, islands of evidence. Exceptionality, 11, 191-208.

Knivsberg, A. M., Reichelt, K. L., Hoien, T., \& Nodland, M. (2003). Effect of a dietary intervention on autistic behavior. Focus on Autism and Other Developmental Disabilities, 18, 247-256.

Laski, F. (1997). IDEA, amended or not, the past is prologue. Journal of the Association for Persons with Severe Handicaps, 22, 77-79.

Lipsey, M. W. (1992). Juvenile delinquency treatment: A meta-analytic inquiry into the variability of effects. In T. D. Cook, H. Cooper, D. S. Corday, H. Hartman, L. V. Hedges, R. J. Light, T. A. Louis, \& F. Musteller (Eds.), Meta-analysis for explanation: A casebook (pp. 83-125). New York: Russell Sage.

Mainzer, R. W., Deshler, D., Coleman, M. R., Kozleski, E., \& Roderiguez-Walling, M. (2003). To ensure the learning of every child with a disability. Focus on Exceptional Children, 35(5), $1-12$.

Mandlawitz, M. (2006). What every teacher should know about IDEA 2004. Boston: Allyn and Bacon.

Mattes, J. (1983). The Feingold diet: A current reappraisal. Journal of Learning Disabilities, 16, 319-323. 
Mauer, D. M. (1999). Issues and applications of sensory integration theory and treatment with children with language disorders. Language, Speech, and Hearing Services in the Schools, 30, 383-392.

McDonnell, J., Hardman, M. L., \& McGuire, J. (in press). Teaching and learning in secondary education. In L. Florian (Ed.), The handbook of special education. London: Sage.

McGrath, M. Z., Johns, B. H., \& Mathur, S. R. (2004). Is history repeating itself-Services for children with disabilities endangered. TEACHING Exceptional Children, 37(1), 70-71.

McGrew, K. S., Vanderwood, M., Thurlow, M. L., \& Ysseldyke, J. E. (1995). Why we can't say much about the status of students with disabilities during educational reform. (Synthesis Report 21). Minneapolis, MN: University of Minnesota, National Center on Educational Outcomes.

McLaughlin, M. (1998). Special education in an era of school reform: An overview. Washington, DC: Federal Resource Center for Special Education.

McLaughlin, M. J., \& Tilstone, C. (2000). Standards and curriculum. The core of educational reform. In M. Rouse \& M. J. McLaughlin (Eds.), Special education and school reform in the United States and Britain (pp. 38-65). London: Routledge.

McLaughlin, M. J., Fuchs, L., \& Hardman, M. (1999). Individual rights to education and students with disabilities: Some lessons from U.S. Policy. In H. Daniels and P. Garner (Eds.), Inclusive education: World yearbook of education 1999 (pp. 24-35). London: Kogan Page.

McNeil, L. M. (2003). Creating new inequalities: Contradictions of reform. Phi Delta Kappan, 84, 729-734.

Moos, R. H. (2005). Iatrogenic effects of psychosocial interventions for substance use disorders: Prevalence, predictors, prevention. Addiction, 100, 595-604.

Mostert, M. P. (2001). Facilitated communication since 1995: A review of published studies. Journal of Autism and Developmental Disorders, 31, 287-313.

Mostert, M. P., \& Crockett, J. B. (2000). Reclaiming the history of special education for more effective practice. Exceptionality, 8, 133-143.

Muller, E (2002). Statewide behavior initiatives: Literature review and survey results. Alexandria, VA: National Association of State Directors of Special Education.

National Parent Teacher Association. (2005). Elementary and Secondary Education Act. Chicago, IL: Author. Retrieved May 23, 2005, from http://www.pta.org//ptawashington/issues/esea.asp

National Research Council. (1997). Educating one and all: Students with disabilities and standards-based reform. Washington, DC: National Academy Press.

National Research Council. (2001). Educating children with autism. Washington, DC: National Academy Press.

Nelson, C. M. (2003). Through a glass darkly: Reflections on our field and its future. Behavioral Disorders, 28, 212-216.

O'Connor, R. (2000). Increasing the intensity of intervention in kindergarten and first grade. Learning Disabilities Research and Practice, 15, 43-54

Olson, S. F. (2005). American Academy of Neurology development of a position on stem cell research. Neurology, 64, 1674.

Patterson, G. R., Dishion, T. J., \& Yoerger, K. (2000). Adolescent growth in new forms of problem behavior: Macro- and micro-peer dynamics. Prevention Science, 1, 3-13.
Peterson, J. M., \& Hittie, M. M. (2003). Inclusive teaching: Creating effective schools for all learners. Boston: Allyn and Bacon.

Polsgrove, L. (2003). Reflections on the past and future. Behavioral Disorders, 28, 221-226.

Powell, N. R., \& Lochman, J. E. (2004). Multidimensional treatment foster care: A conceptually based empirically validated approach to treating antisocial behavior in youth. Contemporary Psychology, 49, 788-790.

President's Commission on Excellence in Education (2002). A new era: Revitalizing special education for children and families. Washington, DC: Educational Publications Center, U.S. Department of Education.

Putnam, J. W., Spiegel, A. N., \& Bruininks, R. H. (1995). Future directions in education and inclusion of students with disabilities: A delphi investigation. Exceptional Children, 61, 553-576.

Reid, D. K., Robinson, S. J., \& Bunsen, T. D. (1995). Empiricism and beyond: Expanding the boundaries of special education. Remedial and Special Education, 16, 131-141.

Rimland, B. (1973). High-dosage levels of certain vitamins in the treatment of children with severe mental disorder. In D. Hawkins \& L. Pauling (Eds.), Orthomolecular psychiatry (513-538). New York: W. H. Freeman \& Co.

Rimland, B., \& Larson, G. E. (1983). Hair mineral analysis and behavior: An analysis of 51 studies. Journal of Learning Disabilities, 16(5), 279-285.

Romanczyk, R. G., \& Goren, E. R. (1975). Severe self-injurious behavior: The problem of clinical control. Journal of Consulting and Clinical Psychology, 43, 730-739.

Rose, D. H., \& Meyer, A. (2002). Teaching every student in the digital age: Universal design for learning. Alexandria, VA: Association for Supervision and Development.

Rouse, M., Shriner, J. G., \& Danielson, L. (2000). National assessment and special education in the United States and England and Wales. In M. J. McLaughlin \& M. Rouse (Eds.), Special education and school reform in the United States and Britain (pp. 66-97). New York: Routledge.

Rueda, R. (2005). Searching for the grand unifying theory: Reflections on the field of LD. Learning Disability Quarterly, 28, 168-170.

Sasso, G. M. (2001). The retreat from inquiry and knowledge in special education. Journal of Special Education, 34, 178-193.

Sebba, J., Thurlow, M. L., \& Goertz, M. (2000). Educational accountability and students with disabilities in the United States and England and Wales. In M. J. McLaughlin \& M. Rouse (Eds.), Special education and school reform in the United States and Britain (pp. 98-125). New York: Routledge.

Schumm, J. S., \& Vaughn, S. (1991). Making adaptations for mainstreamed students: General classroom teachers' perspectives. Remedial and Special Education, 12(4), 18-27.

Shaywitz, B. L., Siegel, N. J., \& Pearson, H. A. (1977). Megavitamins for minimal brain dysfunction: A potentially dangerous therapy. Journal of the American Medical Association, 238, 1749-1750.

Sieben, R. L. (1977). Controversial medical treatments of learning disabilities. Academic Therapy, 13, 133-147.

Silver, L. B. (1987). The "Magic Cure": A review of the current controversial approaches to treating learning disabilities. Journal of Learning Disabilities, 20, 498-504.

Speckart, G., \& Bentler, P. M. (1982). Application of attitude-behavior models to varied content domains. Academic Psychology Bulletin, 4, 453-465. 
Stein, M., Carnine, D., \& Dixon, R. (1998). Direct instruction: Integrating curriculum design and effective teaching practices. Intervention in School and Clinic, 33, 227-234.

Sugai, G. (1998). Postmodernism and emotional and behavioral disorders: Distraction or advancement? Behavioral Disorders, 23, 171-177.

Sugai, G., \& Horner, R. (2002). The evolution of discipline practices: School-wide positive behavior supports. Child \& Family Behavior Therapy, 24(1-2), 23-50.

Tarver, S. (1996). Direct instruction. In W. Stainback \& S. Stainback (Eds.), Controversial issues confronting special education: Divergent perspectives (2nd ed.) (pp. 143-152). Boston: Allyn and Bacon.

Thurlow, M. L. (2000). Standards-based reform and students with disabilities: Reflections on a decade of change. Focus on Exceptional Children, 33(3), 1-15.

Torgesen, J. K. (1996). The prevention and remediation of reading disabilities. John F. Kennedy Center Distinguished Lecture Series. Nashville, TN: Vanderbilt University.

U. S. Department of Education, Office of Special Education and Rehabilitative Services (2002). A new era: Revitalizing special education for children and their families. Washington, DC: U.S. Government Printing Office.

VanDyke, D. C., Lange, D. J., Heide, F., van Duyne, S., \& Soucek, M. J. (1990). Clinical perspectives in the management of Down syndrome. New York: Springer-Verlag Publishing.
Vezie, M. B. (1975). Sensory integration: A foundation for learning. Academic Therapy, 10, 345-354.

Wagschall, P. H., \& Lucas, J. A. (1983). Judgmental forecasting techniques and institutional planning: An example. New Directions for Institutional Research, 39, 39-49.

Webber, J., \& Scheuermann, B. (1997). A challenging future: Current barriers and recommended action for our field. Behavioral Disorders, 22, 167-178.

Werch, C. E., \& Owen, D. M. (2002). Iatrogenic effects of alcohol and drug prevention programs. Journal of Studies on Alcohol, 63, 581-590.

Wheeler, D. (1993). An experimental assessment of facilitated communication. Mental Retardation, 31, 49-60.

Winzer, M. A. (1993). The history of special education: From isolation to integration. Washington, DC: Galludet University.

Zigmond, N. (2001). Special education at a crossroads. Preventing School Failure, 45, 70-74.

Zigmond, N., \& Baker, J. M. (1995). Concluding comments: Current and future practices in inclusive schooling. Journal of Special Education, 29, 245-250.

Marcia L. Rock extends sincere appreciation to Drs. Edwin Ellis, Madeleine Gregg, and Inez Rovegno. 


\title{
Curriculum Planning and Instructional Design for Gifted Learners
}

\author{
Joyce VanTassel-Baska
}

This comprehensive text establishes an exciting curriculum design model that caters to the unique needs of the gifted learner. While giving careful consideration to the current climate of educational reform, the text is able to preserve and enhance the important enterprise of gifted education.

The author's extensive experience in the field of gifted education makes this text an invaluable resource for students and teachers alike. Impressive in scope, the text gives thorough attention to crucial issues such as effective curriculum delivery, implementation strategies, and learner-outcome assessment.

Curriculum goals, learner outcomes, teacher-learning activities, instructional strategy design and selection, and management activities are among the important topics addressed in the individual chapters. The latter part of the book contains specific helpful sample curriculum units that exemplify strategies described throughout the book.

\section{SPECIAL FEATURES}

- Provides a comprehensive framework for curriculum planning.

- Designs an effective planning model for instruction.

- Outlines specific instructional strategies and curriculum units.

- Presents guidelines for learning assessment and curriculum evaluation.

\section{CONTENTS}

1. Introduction

2. Research on Curriculum Models in Gifted Education

3. Standards of Learning and Gifted Education

4. Developing Systemwide Curriculum Documents

5. The Nature and Curriculum Needs of Gifted Learners

6. Developing a Philosophy and Goals for a Gifted Program

7. Developing Learner Outcomes

8. Designing Activities and Selecting Resources

9. Selecting Instructional Strategies

10. Employing Appropriate Curriculum Management Strategies

11. Implementing Curricula for the Gifted

12. Assessment of Learning and Evaluation of Curriculum

13. Toward Coherent Curriculum Policy in Gifted Education Appendix: Sample Curriculum Units

\$54.00 / Paperback / 384 pages / ISBN 0-89108-292-1

Love Publishing Company

9101 E. Kenyon Ave., Suite 2200

Denver, CO 80237

303-221-7333 • 303-221-7444 (fax) 


\section{Professional update}

CEC Division of Learning Disabilities Annual Conference

November 3-4, 2006

Palace Hotel

San Francisco, California

Contact: Charles Hughes (814) 863-1699 cah14@psu.edu TeachingLD.org

\section{American Speech-Language-Hearing Association} Annual Conference

November 16-18, 2006

Miami Beach Convention Center

Miami Beach, Florida

Contact: ASHA

10801 Rockville Pike

Rockville, MD 20852

\author{
Ontario (Canada) CEC 50th Annual \\ Provincial Conference \\ November 9-11, 2006 \\ Sheraton Parkway, Richmond Hill \\ Ontario, Canada \\ Contact: Cindy Perras \\ cindy.perras@peelsb.com
}

\section{CEC Annual Convention}

April 18-21, 2007

Louisville, Kentucky

Contact: Council for Exceptional Children (888) 232-7733

conteduc@cec.sped.org 